DOI 10.31558/2519-2949.2019.1.12

УДК 327.82:004(73)

ORCID ID: https://orcid.org/0000-0002-7716-085X

Тихоненко І. В., Чорноморський національний університет імені Петра Могили

\title{
ЦИФРОВА ДИПЛОМАТІЯ ЯК ІНСТРУМЕНТ ЗОВНІШНЬОЇ ПОЛІТИКИ США У ХХІ СТОЛІТТІ
}

У статті розглядаються особливості иифрової дипломатії як нового інструменту ведення зовнішньої політики держави у XXI cm. у зв 'язку із поширенням інформаційно-комунікаційних технологій. Особливості цифррової дипломатії проаналізовано на прикладі США, як держави, яка активно застосовує ией вид дипломатії. Зокрема, охарактеризовано механізми використання ицирової дипломатії на інституційному рівні у сфері зовнішньополітичної діяльності США, щзо імплементується у наступному. По-перше, виявлено еволюиію використання електронної дипломатії у XXI cm. за адміністрачій Дж. Буша-молодшого, Б. Обами та Д. Трампа. Зокрема, відкриття у 2003 р. Офісу цифрової дипломатії при Держдепартаменті США за адміністраиії Дж. Буша молодшого та широке використання твітпломатії адміністрачією Д. Трампа. По-друге, впровадження та використання так званих нових медіа як сфери діяльності иифрової дипломатіївикористання сочіальних мереж (Facebook, Twitter, YouTube), створення мікроблогів (DipNote та діяльність проекту діплопедія, який наближує дипломатів до громадян держави перебування).

Використання нових медіа створює сприятливий мікроклімат для поширення зовнішньополітичних ініціатив США за кордоном завдяки віртуальному контакту з громадянами інших держав та донесення до них певного інформаиійного контенту (використовуючи їх рідну мову, а не англійську), що безпосередньо пропагує американські иінності та національні інтереси у вигідному для Вашингтону ракурсі. Хоча такі методи не зовсім ліберальні та демократичні, але виправдовують концепцію «м'якої сили» у зовнішній політииі держави. Автор акцентує увагу на вагомості механізмів цифрової дипломатії зовнішній політиці США у сучасних реаліях, щэо підтверджено практичним ї̈ застосування президентом США Д. Трампом через сочіальну-мережу Twitter. Виявлено, що деякі заяви президента у соиіальні мережі можуть йти у розріз із задекларованим зовнішньополітичним курсом США, проте, крізь призму твітів президента можна прослідкувати еволюиію та стан двосторонніх відносин Америки з іншими державами (зокрема, на прикладі американсько-пакистанських відносин).

Ключові слова: ичифрова дипломатія, зовнішня політика, США, Д. Трамn, Twitter.

Постановка проблеми. Міжнародні відносини у XXI ст. характеризуються низкою нововведень, серед яких є поява нових інструментів реалізації зовнішньої політики держави. Зокрема цифрова дипломатія (digital diplomacy), яку досить активно використовують США. Вона грунтується на прагненні уряду США розширити число прихильників американських цінностей за кордоном $\mathrm{i}$ залучити міжнародну громадськість в політичний порядок денний, запропонований Вашингтоном. Актуалізується дана проблематика у зв'язку із активним використанням Twitter американським президентом Д. Трампом, що є проявом цифрової дипломатії в дії і має безпосередній вплив на американські двосторонні та багатосторонні відносини у міжнародній сфері.

Аналіз останніх досліджень і публікацій. Теоретичну базу дослідження склали праці праці українських (М. С. Гринчук, С. А. Гуцал, Н. О. Піпченко, Я. Турчин) та зарубіжних (Е. Гільбоа, М. Гарбон, М. Епова, Н. Цвєткова) дослідників, які акцентують увагу на сутності та характерних рисах електронної та цифрової дипломатії, а також основних iï аспектах у зовнішній політиці США.

Метою даного дослідження $\epsilon$ аналіз особливостей цифрової дипломатії як інструменту зовнішньої політики США, іiі механізмів та втілення. Поставлена мета передбачає вирішення наступних завдань:

- визначення поняття цифрової дипломатіі;

- аналіз нормативно-правової бази та механізму інституційного забезпечення реалізації цифрової дипломатії в США;

(C) Тихоненко I. B., 2019 
- характеристика ефективності електронної дипломатії у практичній сфері реалізації американського зовнішньополітичного курсу (на прикладі адміністрації Д. Трампа);

Виклад основного матеріалу. Термін е-дипломатія, що позначає широке використання інформаційно-комунікаційних технологій для здійснення державними органами своїх функцій та комунікацій у сфері зовнішньої політики, вперше почали використовувати у США. Е-дипломатія $\epsilon$ одним із напрямів американської громадської дипломатії, яка спрямована на залучення широких верств населення до дипломатичної практики та налагодження міжнародної взаємодії. Американська модель е-дипломатії базується на ліберальних цінностях демократії та свободи людини, реалізується через низку відомих інтернет-індустрій США - Google, Facebook, Twitter тощо [7, с. 104.].

Використання цифрової дипломатії розпочалося у 1996 р., що пов'язано із діяльністю інформаційного агентства США - ЮCIA (USIA, United States Information Agency), яке сформувало перший інтернет-журнал Washington Files. Першим кроком у розвитку електронної дипломатії було розміщення матеріалів на офіційних сайтах дипломатичних представництв Сполучених Штатів. Згодом розрізнені матеріали стали об'єднуватися в Електронні журнали Уряду США [3, с.109.].

У 2001 р. США оголосили про створення мережевої дипломатії. Програми цифрової дипломатії в США отримали розвиток в 2002-2003 pр., коли адміністрація Дж. Буша-молодшого почала переносити традиційні радіо- і телеканали міжнародного мовлення в Інтернет. Тоді ж колишня держсекретар К. Райз оголосила про запуск першого офіційного блогу Держдепу, відкрила урядовий портал і кілька електронних журналів.

До завдань цифрової дипломатії також входить підтримка молодіжних рухів. Одним з найбільш успішних став, організований за допомогою соціальної мережі Facebook, рух, який переріс в масову хвилю протестів проти Революційних збройних сил Колумбії - Армії народу в 2008 р. Трохи пізніше за американською ініціативою був створений так званий Альянс молодіжних рухів, який об'єднав молодих людей, охочих використовувати нові технології в політичних цілях. На сайті Альянсу розміщені інструкції зі створення блогів і запуску кампаній в соціальних медіа [5, с. 17-18.].

Важливу роль в здійсненні цифрової дипломатії США в країнах Близького Сходу грає Команда 3 цифрових зовнішніх контактів (Digital Outreach Team), яка була створена в 2006 р. До завдань команди входить участь в дискусіях з питань зовнішньої політики США з користувачами популярних сайтів арабською і перською мовами, а також урду. Створення дослідницького центру в 2007 р. з вивчення блогосфери в зарубіжних країнах надало уряду США широкі можливості 3 пошуку і підтримки демократичних настроїв, зокрема, у арабських країнах [1, с. 30-31.].

Цифрова дипломатія Сполучених Штатів Америки здійснюється Державним департаментом США і агентством США з міжнародного розвитку (АМР США). Для адаптації до змін ХХІ ст. Держдепартамент США провів низку перетворень в здійсненні дипломатії, наприклад, в 2003 р. в рамках Бюро з управління інформаційними ресурсами США був відкритий Офіс 3 цифрової дипломатії, робота якого спрямована на розвиток інформаційних і технічних ресурсів. Блогери створюють відео, перекладають інформацію на інші мови, представляючи інформацію у вигляді коротких повідомлень. У 2011 р. був запущений Twitter арабською, перською, російською, французькою, іспанською мовами, що дозволяє обійти використання тільки англійської мови у реалізації цифрової дипломатії [4, с. 212.].

Чільне місце у розвитку цифрової дипломатії Вашингтону посідає проект діплопедія, що був започаткований у 2006 р. Державним департаментом США. Це - діяльність міністерств в Інтернет площині. Діплопедія є частиною програми, що трансформувала дипломатію К. Райс і робить акцент на нові медіа, такі як Facebook, YouTube, Twitter. Ще один проект, розроблений Офісом з електронної дипломатії - Віртуальний студент дипломатичної служби. Це - інтернет-програма стажувань, надаючи студентам вузів можливість брати участь в дипломатичній місії. Все це $\epsilon$ прикладами успішного здійснення цифрової дипломатії Держдепартаменту США [8, с. 173.].

У 2010-2011 pр. Білим домом були опубліковані кілька офіційних документів, які задають напрямки електронної дипломатії. У їх числі був документ «Публічна дипломатія: зміцнення взаємодії Сполучених Штатів зі світом», де позначалися завдання, які визначаються керівництвом США для електронної дипломатії. Зокрема, в список таких завдань увійшли: 1) дискредитація ідеологічних супротивників Сполучених Штатів; 2) протидія інформаційної діяльності Китаю в Інтернеті; 3) обмеження медіа присутності Росії на просторі колишнього Радянського Союзу; 4) протидія зовнішньої культурної політики Ірану, яка проводилася через соціальні мережі [17]. 
Залучення зарубіжних товариств до цінностей США і використання мережі Інтернет як інструменту координації зусиль Вашингтону і зарубіжної цільової аудиторії стало центральним лейтмотивом зміцнення «м'якої» і «розумної сили» адміністрації Б. Обами в 2010-2012 рр. Зокрема, використання цифрової дипломатії США на тлі соціально-політичних протестів в Північній Африці i на Близькому Сході (створення численних віртуальних неурядових організацій, які пропагували цінності лібералізму арабською та англійською мовами) [11, с. 125-126.].

Сучасна Інтернет-дипломатія США дає широкі можливості, по-перше, щодо коригування змісту інформаційної пропаганди: глобальна мережа дозволяє оперативно змінити не тільки підбір літератури та інформації з теми, а й організувати дискусію, направляти іiі в певне русло, відстежувати зміни громадської думки. По-друге, активна участь Адміністрації США в соціальних мережах дозволяє персоніфікувати групи молоді, які мають протестні настрої і безпосередньо в режимі реального часу проводити з ними роботу.

Крім цього, існування персональних аккаунтів вищих посадових осіб США, їх політичних інститутів, дозволяє створити видимість особистої живої бесіди з людьми, які відповідають за прийняття рішень в країні $[10$, с. 127.].

Бюро управління інформаційних ресурсів Державного департаменту розробило соціальну мережу «Corridor», що орієнтована на користування нею співробітниками Держдепартаменту та представниками інших владних структур США [2, с. 334-335.]. Блог DipNote був заснований Держдепартаментом США у 2007 р. Платформа сприяє обговоренню США та публічної дипломатії. Частиною філософії даного порталу є цілеспрямований збір позитивних та негативних відгуків учасників дискусій, та подальший їх аналіз з метою оцінювання ставлення до США іноземної публіки. В 2009 р. платформа була реформована - значна увага стала приділятись перекладу на різні мови та узагальненню промов президента та ключових політиків, їх розповсюдження за допомогою Twitter та інших соціальних мереж [6, с. 225.]. Варто зауважити, що наразі існує близько 40 віртуальних представництв США за кордоном.

Усі ці програми та сервіси не лише теоретично функціонують, а й дійсно виправдовують свою діяльність на практиці. Варто зазначити, що президент США Д. Трамп безпрецедентно активно, як для глави США, використовує свій аккаунт в Twitter. Це явище вже отримало назву Twitterдипломатії. Наприклад, в своєму мікроблозі Д. Трамп повідомив про одну з найбільш резонансних номінацій для своєї адміністрації - кандидата на пост державного секретаря Р. Тіллерсона. Про рішення піти з бізнесу в політику він теж оголосив через свій аккаунт.

Першою заявою, яке підхопили світові ЗМІ, стала загроза Трампа скасувати угоду з Кубою, підписану в 2015 р. Б. Обамою і Р. Кастро, яка відновлює дипломатичні відносини, що були перервані в 1961 році [14].

Досить цікавими є спостереження за еволюцією поглядів Д. Трампа на відносини СШАПакистан, які також стали об'єктом застосування так званої твітломатії. Зокрема, у передвиборчій програмі Д. Трамп у своєму Twitter зазначив: «Коли ж американці вибачаться перед пакистанцям за їх вбивство атаками дронів?» [16], але поряд із цим зазначалося і діаметрально протилежне «Коли Пакистан вибачиться за те, що ховав У. бен Ладена?» [13].

Можна припустити, що такі двозначні заяви були певним піаром перед виборами. Проте, вже будучи Президентом США Д. Трамп визнчив свою позицію щодо Пакистану, що проявилося знову ж із використанням Twitter. Зокрема, у лютому 2018 p. не просто намітилася тенденція до погіршення двосторонніх американсько-пакистанських відносин, а вони справді увійшли у фазу загострення. Початок було покладено постом Д. Трампа у Twitter: «Сполучені Штати вчинили нерозумно, дали Пакистану більше, ніж 33 мільярди доларів як допомогу протягом останніх 15 років, а вони [Пакисан] не дали нам нічого, крім обману і брехні, думаючи про наших лідерів як таких, що є дурнями. Вони надають притулок терористам, на яких ми полюємо в Афганістані, лише трохи допомагають нам. Не більше!» [15].

Така заява Президента обурила пакистанську владу, насамперед, начальника штаба армії Пакистану К. Баджва, під керівництвом якого триває антитерористична операція «Раад-уль-Фасад» у прикордонних з Афганістаном територіях.

Варто наголосити, що дописи Д. Трампа у Twitter щодо Пакистану набули більш позитивного забарвлення наприкінці 2018 р. у зв'язку із політикою прем'єр-міністра Пакистану І. Хана щодо афганського врегулювання [19]. Останнє загострення пакистансько-індійських відносин у лютому 2019 р. у зв'язку із нападом терористів у м. Пулвама (штат Джамму і Кашмір в Індії) знайшло лояльне висвітлення у дописах Президента Америки. Хоча, не можна стверджувати про певні 
кардинальні зміни у американсько-пакистанських відносинах, адже, насамперед Вашингтону як і всій світовій спільноті невигідною не війна між двома ядерними державами [18].

Отже, навіть твіти в соціальних мережах здатні погіршити відносини між країнами або стати показником їх динаміки. Роль електронної дипломатії все більше зростає, тому можна припустити, що через деякий час даний вид дипломатії стане звичайним явищем у політиці та міжнародних відносинах.

На сьогодні у США ведеться дуже багато дискусій щодо законодавчого забезпечення сфери цифрової дипломатії, щодо питань можливостей iï реорганізації, відповідальних управлінських структур, висуваються вимоги до посилення міжінституційної кооперації та координування. Нині більша частина рекомендацій стосовно необхідності реформування структури цифрової дипломатії стосуються закликів до створення нового агентства або іншої управлінської одиниці з метою позбавлення Держдепартаменту відповідальності за дану сферу або реорганізації структури зовнішньополітичного відомства з метою кращої адаптації функцій публічної дипломатії [10, с. 375.].

Висновки. Використання ресурсного потенціалу електронної або цифрової дипломатії для забезпечення лідерських позицій у світі та втілення зовнішньополітичного курсу у США знаходить своє відображення на інституційному рівні. Насамперед у діяльності Державного департаменту США (Бюро управління інформаційних ресурсів) і агентства США з міжнародного розвитку, які створюють відповідні програми як для модернізації роботи дипломатів, так i поширення американських цінностей та політики назагал у площину медіа та Інтернет. Зокрема, активне залучення нових-медіа - соціальних мереж та блогів до реалізації зовнішньополітичного курсу Вашингтоном підтверджується використанням Twitter президентом США Д. Трампом. Варто зауважити, що деякі заяви Президента у соціальній мережі випереджають і йдуть у розрізі із заявленим курсом США, але водночас привертають увагу світової спільноти до Америки. Тож, застосування цифрової дипломатії має більше переваг, аніж недоліків і дає змогу суттєво посилити вплив держави на міжнародній арені, реалізувати національний інтерес у сучасному глобалізованому світі.

Перспективи подальшого дослідження вбачаємо у більш детальному аналізі твітпломатії та iii використання не лише США, а й іншими державами як інструменту реалізації зовнішньої політики.

\section{Бібліографічний список}

1. Гавриленко І. І. Геополітичний вимір публічної дипломатії США. Міжнародні відносини. Серія «Політичні науки». 2014. № 3. С. 25-38.

2. Гринчук М.С. Цифрова дипломатія США. Гілея: науковий вісник. 2016. Вип. 112. С. 334-336.

3. Гуцал С. А. Публічна дипломатія як сучасний пріоритет зовнішньої політики держави. Стратегічні пріоритети. 2010. № 3(16). С. 106-114.

4. Зиновьева Е. Цифровая дипломатия, международнавя безопасность и возможности для России. Индекс безопасности. 2013. № 1. С. 212-228.

5. Піпченко Н. О. Цифрова дипломатія як інструмент зовнішньополітичної діяльності США. Міжнародні відносини. Серія «Політичні науки». 2015. № 5. С. 15-26.

6. Сурма И. В. Цифровая дипломатия в мировой политике. Государственное управление. Электронный вестник. 2015. № 49. С. 220-250.

7. Турчин Я. Електронна дипломатія як важлива складова зовнішньої політики держави. Інформація, комунікація, суспільство. 2014. С. 104-105.

8. Турчин Я. Інституційні правові основи е-дипломатії США. Інформація, комунікація, суспільство. 2016. C. $172-173$.

9. Турчин Я. Теорія і практика е-дипломатії у сучасних міжнародних відносинах. Гілея: науковий вісник: зб. наук. пр. К.: Вид-во НПУ ім. М.П. Драгоманова, 2013. Вип. 74. № 7. С. 373-376. C. $126-131$

10. Федоров О. Д. Новые тенденции в публичной дипломатии США. Вектор науки ТГУ. 2014. № 2(28).

11. Цветкова Н. Публичная дипломатия США от «мягкой силы» к диалоговой пропаганде». Международные процессы. 2015. № 3(42). С. 121-134.

12. Эпова М. А. Появление цифровой дипломатии и американский опыт. Электронный научнопрактический журнал «История и археология». 2015. № 3. URL: http://history.snauka.ru/2015/03/1767

13. Chakravarty S. Donald Trump wins: What it could mean for Pakistan. The Times of India. 9.11.2016. URL: http://timesofindia.indiatimes.com/united-states-elections-2016-us-elections-news-results-polls/Donald-Trumpwins-What-it-may-mean-for-Pakistan/articleshow/55331638.cms

14. Donald J. Trump on Twitter: The people of Cuba have struggled too... Twitter. URL: https://twitter.com/realdonaldtrump/status/786285509668696065 
15. Donald J. Trump on Twitter: The United States has foolishly given... Twitter.

URL: https://witter.com/realdonaldtrump/status/947802588174577664?lang=ru

16. Michel A. H. The Presidential Candidates on Drones. Center for the Study of the Drone. 16.10.2015.

URL: http://dronecenter.bard.edu/presidential-candidates-on-drones/

17. Public Diplomacy: Strengthening U.S. Engagement with the World. USC Center on Public Diplomacy.

URL: https://uscpublicdiplomacy.org/sites/uscpublicdiplomacy.org/files/legacy/pdfs/PD_US_World_Engagement.pdf

18. Trump says there's "reasonably decent" news on the India-Pakistan conflict and "hopefully" it's coming to

an end // Twitter. URL: https://mobile.twitter.com/BloombergAsia/status/1101019535983837184

19. We have some good news, India-Pakistan tension may end soon, hints Donald Trump // The Economist.

2019. February 28. URL: https://economictimes.indiatimes.com/news/international/world-news/we-have-good-newsfrom-india-pakistan-tensions-may-end-soon-us-president-donld-trump/articleshow/68198388.cms

\section{References:}

1. Gavry`lenko I. I. Geopolity`chny`j vy`mir publichnoyi dy`plomatiyi SShA. Mizhnarodni vidnosy`ny`. Seriya «Polity`chni nauky`». 2014. \# 3. S. 25-38.

2. Gry`nchuk M.S. Cy`frova dy`plomatiya SShA. Gileya: naukovy`j visny`k. 2016. Vy`p. 112. S. 334-336.

3. Guczal S. A. Publichna dy`plomatiya yak suchasny`j priory`tet zovnishn`oyi polity`ky` derzhavy`.

Strategichni priory`tety`. 2010. \# 3(16). S. 106-114.

4. Zinov'eva E. Cifrovaya diplomatiya, mezhdunarodnavya bezopasnost' i vozmozhnosti dlya Rossii. Indeks bezopasnosti. 2013. № 1. S. 212-228.

5. Pipchenko N. O. Cy`frova dy`plomatiya yak instrument zovnishn`opolity`chnoyi diyal`nosti SShA.

Mizhnarodni vidnosy`ny`. Seriya «Polity`chni nauky`». 2015. \# 5. S. 15-26.

6. Сурма И. В. Цифровая дипломатия в мировой политике. Государственное управление. Электронный вестник. 2015. № 49. С. 220-250.

7. Turchy`n Ya. Elektronna dy`plomatiya yak vazhly`va skladova zovnishn`oyi polity`ky` derzhavy`.

Informaciya, komunikaciya, suspil`stvo. 2014. S. 104-105.

8. Turchy`n Ya. Insty`tucijni pravovi osnovy` e-dy`plomatiyi SShA. Informaciya, komunikaciya, suspil`stvo. 2016. S. 172-173.

9. Turchy`n Ya. Teoriya i prakty`ka e-dy`plomatiyi u suchasny`x mizhnarodny`x vidnosy`nax. Gileya: naukovy`j visny`k: zb. nauk. pr. K.: Vy`d-vo NPU im. M.P. Dragomanova, 2013. Vy`p. 74. \# 7. S. 373-376.

10. Fedorov O. D. Novye tendencii v publichnoj diplomatii SSHA. Vektor nauki TGU. 2014. № 2(28). S. 126-131.

11. Cvetkova N. Publichnaya diplomatiya SSHA ot «myagkoj sily» k dialogovoj propagande».

Mezhdunarodnye processy. 2015. № 3(42). S. 121-134.

12. Ehpova M. A. Poyavlenie cifrovoj diplomatii i amerikanskij opyt. Ehlektronnyj nauchno-prakticheskij zhurnal «Istoriya i arheologiya». 2015. № 3. URL: http://history.snauka.ru/2015/03/1767

13. Chakravarty S. Donald Trump wins: What it could mean for Pakistan. The Times of India. 9.11.2016.

URL: http://timesofindia.indiatimes.com/united-states-elections-2016-us-elections-news-results-polls/Donald-Trumpwins-What-it-may-mean-for-Pakistan/articleshow/55331638.cms

14. Donald J. Trump on Twitter: The people of Cuba have struggled too... Twitter.

URL: https://twitter.com/realdonaldtrump/status/786285509668696065

15. Donald J. Trump on Twitter: The United States has foolishly given... Twitter.

URL: https://witter.com/realdonaldtrump/status/947802588174577664?lang=ru

16. Michel A. H. The Presidential Candidates on Drones. Center for the Study of the Drone. 16.10.2015.

URL: http://dronecenter.bard.edu/presidential-candidates-on-drones/

17. Public Diplomacy: Strengthening U.S. Engagement with the World. USC Center on Public Diplomacy. URL: https://uscpublicdiplomacy.org/sites/uscpublicdiplomacy.org/files/legacy/pdfs/PD_US_World_Engagement.pdf

18. Trump says there's "reasonably decent" news on the India-Pakistan conflict and "hopefully" it's coming to an end // Twitter. URL: https://mobile.twitter.com/BloombergAsia/status/1101019535983837184

19. We have some good news, India-Pakistan tension may end soon, hints Donald Trump // The Economist. 2019. February 28. URL: https://economictimes.indiatimes.com/news/international/world-news/we-have-good-newsfrom-india-pakistan-tensions-may-end-soon-us-president-donld-trump/articleshow/68198388.cms

\section{Tykhonenko I. V. Digital diplomacy as an instrument of US foreign policy in the 21st century}

The article considers the peculiarities of digital diplomacy as a new instrument of foreign policy in the 21 st century in connection with the spread of information and communication technologies. Mechanisms of digital diplomacy are analyzed on the example of the United States as a state that actively uses this type of diplomacy. In particular, the mechanisms of digital diplomacy at the institutional level in the field of foreign policy of the USA are described by following aspects. First, the evolution of the use of electronic diplomacy in the 21st century was revealed for the administrations of George W. Bush, B. Obama and D. Trump. In particular, opening of the Office of Digital Diplomacy at the US Department of State in 2003 
by J. Bush's administration and widespread using of new media by D. Trump's administration. Secondly, the introduction and use of so-called new media as a field of digital diplomacy - the use of social networks (Facebook, Twitter, YouTube), the creation of microblogging (DipNote and project diplomacy activities that bring diplomats closer to citizens of the host country).

The use of new media creates a favorable microclimate for the spread of US foreign policy initiatives abroad through virtual contact with citizens of other countries and the dissemination of certain information content (using their mother tongue rather than English), which directly promotes American values and national interests beneficial to Washington. Although such methods are not quite liberal and democratic, they justify the concept of "soft power" in the foreign policy of the state.

The author focuses on the importance of the mechanisms of digital diplomacy for US foreign policy in modern realities, as confirmed by the practical application of US President D. Trump via Twitter's social network. It has been found that some of the president's statements in social networks may go against the declared foreign policy of the United States. However, through the prism of the president's tweets, one can observe the evolution and present stage of America's bilateral relations with other countries (in particular, on the example of American-Pakistani relations).

Key words: digital diplomacy, foreign policy, USA, D. Trump, Twitter. 